\title{
Science, Business, and Policy: A long-term reflection on multidisciplinary work-based learning in a master's track for societal integration of Science
}

\author{
Saskia Grooters, Emma L. Zaal, and Menno P. Gerkema*
}

doi: http://dx.doi.org/10.18543/tjhe-8(2)-2021pp119-164

Received: 3 December 2020

Accepted: 9 April 2021

\begin{abstract}
A strong theoretical approach with a specific focus on disciplinary research characterizes the common science master's education in the Netherlands. However, a work-based learning (WBL) approach may as well be expedient and suitable for science education at master's level. In this paper, a case study is presented of a WBL-program designed for an academic setting: the one year Science, Business and Policy (SBP) master's track, offered at the Faculty of Science and Engineering of the University of Groningen. The paper describes the design and curriculum of the track, including its underlying theoretical framework, courses, multidisciplinary projects and work placements. Based on the SBP-track's design we identified six possible indicators of a successful elaboration of an academic WBL-program: the SBP-track 1) is designed in response to the Bologna process; 2) is offered fully within the curriculum of a master's program of a research university; 3) requires a sufficient academic level and disciplinary knowledge at entrée; 4) follows an educational project approach; 5) focuses on the integration and implementation of knowledge, and; 6) applies learning objectives that are specifically formulated to match the WBL educational method.

A directed content analysis of SBP work placements revealed an increase in the number of SBP-students between 2003 and 2019, with an overrepresentation of life
\end{abstract}

* Saskia Grooters (s.grooters@rug.nl) is lecturer and coordinator of the work-based learning track Science, Business and Policy (SBP) at the Faculty of Science and Engineering of the University of Groningen.

* Emma L. Zaal (e.1.zaal@rug.nl) is a PhD-candidate at the Faculty of Arts, University of Groningen. In her PhD-project, Emma investigates how socially desirable responding can best be predicted, measured and reduced in online questionnaires.

* Menno P. Gerkema (m.p.gerkema@rug.nl) is emeritus professor of Chronobiology, and Science, Business and Policy at the University of Groningen.

More information about the authors is available at the end of this article.

Acknowledgements: We thank M.J. van den Nieuwenhof, Y.P. Ongena, H.J. van der Windt and A. de Vries for their helpful comments and we thank student-assistants Esmee Castermans, Vera Snippe and Romy Krikke for their support. 
science students, as well as a large variety of real-case problems addressed for both business and policy organisations diverse in sector, size and region. Students' grades showed a positive correlation between the initial theoretical preparation and the report made during the work placement. In conclusion, the societal interpretation of the Bologna process has been implemented successfully with SBP, by combining academic learning with gaining professional experience using a WBL-approach.

Keywords: Work-based learning; science, business and policy; curriculum design; science education; interdisciplinary integration; didactic model; work placement.

\section{Introduction}

The necessity to bridge the gap between science and society has become a growing insight of our time. ${ }^{1,2}$ In this perspective we have seen increasing efforts to integrate academic learning and practice-based learning in the past decades. ${ }^{3,4}$ For many universities science-based learning placements at an academic level in business and policy institutions are still a relatively new development. There is yet much to be learned about the determinants of quality and success for academic programs that offer and integrate such placements in their curriculum. In their literature review, Lester, Bravenboer and Webb ${ }^{5}$ conclude:

There are, however, few practically oriented accounts of how 'basic science' or discipline-based knowledge can be integrated with transdisciplinary workplace learning, particularly at the level of initial development.

In addition, the authors stress the need to evaluate work-integrated programs and its curricular models. Here, we present a case study of the

${ }^{1}$ Peter Agre and Alan I. Leshner, "Bridging Science and Society." Science 327 (February 2010): 921. https://doi.org/10.1126/science.1188231.

${ }^{2}$ Robert Wagenaar, REFORM! TUNING the Modernisation Process of Higher Education in Europe: A Blueprint for Student-Centred Learning (Groningen: University of Groningen, 2019), 194-197.

${ }^{3}$ Stan Lester and Carol Costley. "Work-based learning at higher education level: value, practice and critique", Studies in Higher Education 35, No. 5 (August 2010): 561. https://doi. org/10.1080/03075070903216635.

${ }^{4}$ Luigi F. Donà dale Rose and Anna Serbati, " $20{ }^{\text {th }}$ Anniversary of the Bologna Declaration: From overview of processes to ongoing activities and experiences," Tuning Journal for Higher education 6, no. 2 (May 2019): 13-19. http://dx.doi.org/10.18543/tjhe-6(2)-2019pp13-19.

${ }^{5}$ Stan Lester, Darryll Bravenboer and Neville Webb, "Work-integrated degrees: context, engagement, practice and quality." Quality Assurance Agency for Higher Education (September 2016): 34. https://doi.org/10.13140/RG.2.2.35788.21129. 
development of an academic work-based learning master's track that is developed for science students at the University of Groningen, the Netherlands. This work-based learning program (from now on WBL), the Science, Business and Policy (from now on SBP) track, is developed to prepare science students for a science career in business and/or policy.

First, as there is a need to acquire more knowledge about how successful scientific WBL-programs are developed, ${ }^{6}$ the theoretical framework that was used to design the SBP-track, including its curriculum, is deliberated on. Second, there is a need for more comparable qualitative information on WBL-programs to collect more information on the determinants of quality and success for academic WBL-programs. ${ }^{7}$ Therefore, using a directed content analysis, SBP alumni study records between the academic years 2003/2004-2019/2020 are investigated on several variables.

We begin the paper with defining the concept of WBL and placing it in the Dutch university context. After a detailed exposé of the build-up of the WBL master's track SBP we discuss the theoretical considerations and framework of the program, as well as the derived learning goals. The methodology section comprises of a description of the units of analysis and explains why we chose to carry out a directive content analysis in the context of this case study. The results section includes information on several components of alumni study records, like student background and grades. Finally, we discuss six important success factors of the SBP-track based on its design and curriculum, summarize and give (potential) explanations regarding the results of the study record analysis, and discuss future questions on research into academic WBL-programs.

This paper will lay the foundations for a future, more extended evaluation of the societal effectiveness of WBL-approaches that are applied at an academic level. This case study is part of a so-called design-based research program, ${ }^{8}$ that also includes studies on academic professors' perceptions of the degree to which WBL-programs as SBP are perceived as academic; the implications of the SBP-track on alumni's quality perception and career development, and a study on the perceived usefulness of the SBP-track for its societal partners (i.e., work placement organisations).

\footnotetext{
${ }^{6}$ Lester, Bravenboer and Webb, "Work-integrated degrees," 34, http://devmts.org.uk/ wid.pdf.

${ }^{7}$ Lester, Bravenboer and Webb, “Work-integrated degrees," 34, http://devmts.org.uk/ wid.pdf.

8 Terry Anderson and Julie Shattuck, "Design-Based Research: A Decade of Progress in Education Research?” Educational Researcher 41, no. 1 (January 2012): 16-25, https://doi. org/10.3102/0013189X11428813.
} 


\section{I.1. The concept of work-based learning in the Dutch university context}

WBL is a term used for multiple types of education in different settings with different goals. Originally, the development of WBL was seen as a concept to lower costs of higher education. In its further development, mainly in the UK and Australia, WBL was also seen in the broader educational perspective of connecting science and society. ${ }^{9}$ This interpretation comprised a twofold strategy: for students to obtain a better preparation for a sciencebased career outside academia and for societal institutions to obtain access to actual developments in science. ${ }^{10}$ In this article we focus on education within a curriculum of a fulltime master's program on level 7 in the context of the European Qualification Framework. Post-graduate and adult education are excluded. To define WBL we adopt a definition that is commonly used in current projects of the European Union: ${ }^{11}$

WBL is an educational strategy or approach that provides students with real-life work experiences to apply academic knowledge and understanding as well as subject related and generic skills and competences to develop employability skills and competences.

Internationally, there is a division within higher education on WBL described by Lester et al.: ${ }^{12}$

The academic literature indicates continuing debate between 'intellectualist' and 'pragmatist' positions, and discipline-based and transdisciplinary orientations.

This division can also be recognized in the organisation of the Dutch educational system. In the Netherlands, traditionally there is a strong division between research universities, providing education on level 7 (master's) and universities of applied sciences, called institutes for higher education, providing education on level 5 (bachelor's). This division originated due to their own unique histories and development. ${ }^{13}$

9 David Boud and Nicky Solomon, Work-based Learning: A New Higher Education? (Buckingham: SHRE/OU Press, 2001).

10 David Boud, Nicky Solomon and Colin Symes, "New Practices for New Times," in Work-based Learning: A New Higher Education?, ed. David Boud and Nicky Solomon (Buckingham: SHRE/OU Press, 2001), 3-17.

11 "What is Work-based Learning (WBL),", WEXHE, accessed September 29, 2020, https://wexhe.eu/index.php/2017/05/09/what-is-work-based-learning-wbl/.

${ }^{12}$ Lester, Bravenboer and Webb, "Work-integrated degrees," 34, http://devmts.org.uk/ wid.pdf.

${ }^{13}$ Egbert de Weert, "The Netherlands," in International Handbook of Higher Education, ed. James J.F. Forest and Philip, G. Altbach (Dordrecht: Springer, 2006), 899-918. 
Research universities are commonly seen as knowledge institutes where students are prepared for a career in science. Universities of applied sciences are institutes providing vocational higher education, aimed at a professional career outside academia. ${ }^{14}$ This division in focus between Dutch universities led to research universities delivering graduates who are specialized in theoretical and research skills (intellectualist), whereas universities of applied sciences deliver graduates who are specialized in practical skills (pragmatist). In this way, the Dutch educational system's practices lead to the so-called 'theory and practice gap': ${ }^{15,16}$ graduated students from research universities cannot properly link the disciplinary knowledge gained by following theoretical courses with experiences they gain by actual practice in the professional work field, while graduates of vocational education often lack disciplinary knowledge compared to their practical skills.

Over the past decades, the need in Dutch society for professionals who are specialized in theory and practice, for instance combining reflection on their own actions with applicable knowledge of the professional field, has grown considerably..$^{17,18}$ Brew $^{19}$ stresses that - internationally - institutes offering higher education should prepare students to deal with a fastchanging professional environment. As Barnett already stated in 1998, professionals should be able to deal with super-complex knowledge..$^{20}$

Additionally, the Bologna Process, a large reform of the European educational system explicitly aimed at unifying European on policy and quality assurance in higher education, states that higher education in Europe should be based on research at all levels, and comparable criteria and methodologies should be established (e.g., facilitating the international

${ }^{14}$ Didi M.E. Griffioen and Uulkje de Jong, "Opvattingen van Docenten en Niet-docenten over Onderzoek in Het Hbo," Tijdschrift voor het Hoger Onderwijs 28, no. 2, (January 2010): 83.

15 Donald A. Schön, The Reflective Practitioner: How Professionals Think in Action (New York: Basic Books, 1983), 1-374.

${ }^{16}$ Donald A. Schön, Educating the reflective practitioner (San Francisco: Jossey-Bass Publishers, 1987), 1-355.

17 Jacqueline. W.M. Hulst and Frans Leijnse, "De veranderagenda: de organisatie van het onderzoek in de hogescholen," Tijdschrift voor Hoger Onderwijs en Management, no. 1 (2007): 47-54, https://www.themahogeronderwijs.org/het-archief/author/3.

${ }_{18}$ Gerda Geerdink, Els van der Pool and Erik Jansen, "Onderzoek in het hbo op de lerarenopleiding primair onderwijs," Tijdschrift voor Hoger Onderwijs en Management, no 1 (2008): 56-61, https://www.themahogeronderwijs.org/het-archief/author/235.

19 Angela Brew, "Transforming Academic Practice through Scholarship," International Journal for Academic Development 15, no 2 (June 2010): 105-116, https://doi. org/10.1080/13601441003737618.

${ }^{20}$ Ronald Barnett, "Supercomplexity and the university," Social Epistemology 12, no 1 (June 1998): 48, https://doi.org/10.1080/02691729808578859. 
exchange of students). ${ }^{21,22,23,24}$ In response to this, the universities of applied sciences in the Netherlands started to offer more discipline-based and theoryforming (i.e., research-based) programs. Dutch research universities started to narrow the theory and practice gap from the other end, by creating more professional preparation.

\section{I.2. The development of the Science, Business and Policy track as a work- based learning program}

The Bologna process has shaped and structured master's programs of Dutch research universities in several ways. For instance, the policy's aim of synchronizing curricula led Dutch research universities to decide that for Mathematics and Natural Sciences, instead of one-year master's programs, two-year master's programs should be designed, divided into three different orientations: a (traditional) research-, an educational-, and a societal-oriented master's track. The addition of a second master's year allowed for the development of new master's programs, without explicit competition with existing programs. The SBP-track is developed at the University of Groningen, the Netherlands, as a societal-oriented master's track with a WBL-approach. Hence, the Bologna process facilitated the option of offering WBL-oriented programs like the SBP-track fully within the curriculum of research universities.

At the University of Groningen, students can start a master's program when they have obtained a bachelor's degree in science at a research university. After the bachelor, students choose an academic discipline for their two-year master's program (e.g., biomedical sciences). In the first master's year, all students gain disciplinary competences and knowledge by following courses at master's level. In addition, in the first master's year students carry out a research project resulting in a master's thesis (minimum

${ }^{21}$ Stanisław Juszczyk, "The Bologna Process and the European Higher Education Area," Korean journal of European integration 7 (September 2013): 89-115.

${ }^{22}$ Ruth Keeling, "The Bologna Process and the Lisbon Research Agenda: the European Commission's expanding role in higher education discourse," European Journal of Education 41,no 2 (May 2006): 203-223, https://doi.org/10.1111/j.1465-3435.2006.00256.x.

23 “Quality Assurance,” EHEA, accessed September 29, 2020, http://www.ehea.info/ pid34433/quality-assurance.html.

24 "The Bologna Process 2020 - The European Higher Education Area in the new decade," Communiqué of the Conference of European Ministers Responsible for Higher Education, accessed September 29, 2020, https://www.eurashe.eu/library/modernising-phe/ Bologna_2009_Leuven-Communique.pdf. 
of 30 ECTS). In the second master's year, students either choose a continuation of a traditional (research) track, the educational master's or alternatively the SBP-track. In this paper, we will not further elaborate on the educational track and compare the SBP-track exclusively with the research-track.

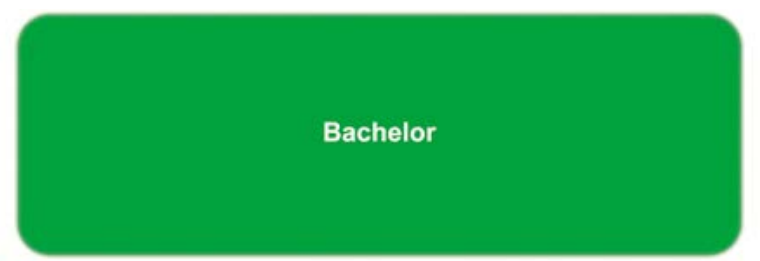

Master year 1 (research, courses, etc.)

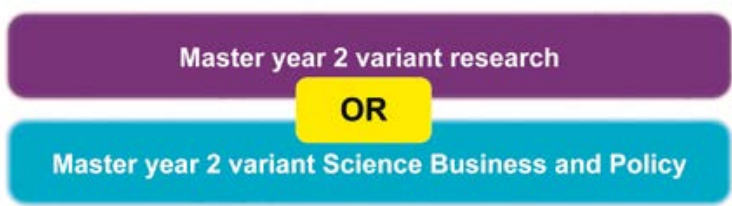

Figure 1

Curriculum design of science study programs of the Faculty of Science and Engineering at the University of Groningen

When students select the research-track, they take disciplinary courses together with other students from a similar disciplinary background. They continue to work on a research project and write a second year master's thesis. In addition, they write a short thesis, prepare and present a colloquium and follow disciplinary master's courses. Students following the researchtrack are specifically prepared for an academic research career (i.e., $\mathrm{PhD}$ trajectory).

When students choose the SBP-track, they are grouped together with students from different disciplinary backgrounds within science. Students take master's courses on business and policy and gain professional experience during a work placement at a business, policy, or non-governmental organisation. Students learn to integrate their science background with some other new disciplines: business and public administration. The SBP-staff consists of a team of coordinating SBP-lecturers, supplemented with tutors, 
guest lecturers, senior academic science specialists and experts from business and policy institutions. This variety of stakeholders were involved from the initial development to the continuing improvement of the SBP-track. Hence, an interdisciplinary team in the SBP-track prepares students for a career at an academic level in a business, policy or non-governmental organisation. Despite its societal focus, after the SBP-track it is also possible to pursue an academic research career (i.e., this is the case for all level 7 academic tracks).

The SBP-track consists of two courses of both 10 ECTS and a workplacement trajectory of 40 ECTS. The first 10 ECTS course is 'Introduction to Science and Business', where students receive a theoretical crash course on business administration and innovation, including a theoretical exam. This is followed by a four-week real case group project - for a company - in which students integrate and apply their knowledge of corporate management with their scientific discipline. Here, students learn integrative competences and combine knowledge from their bachelor's and first master's year with general competences like personal development, project management, communication and soft skills (i.e., a combination of interpersonal and social skills). ${ }^{25}$ The second course, 'Introduction to Science and Policy', has a similar set-up, focusing on policy skills. Students get a theoretical examination on public administration and finish a real case group project of four weeks for a governmental or non-governmental organisation.

The final and largest part of the SBP-track is an individual work placement of 40 ECTS (approximately six months), in which the work-based learning component is put into practice. The actual connection between science and business or policy is made during this fulltime business or policy work placement at an external organisation.


Figure 2

Program design of the Science, Business and Policy track

25 Jami Dixon, Cody Belnap, Chad Albrecht and Konrad Lee, "The Importance of Soft Skills," Corporate Finance Review 14, no 6 (June 2010): 35. 


\section{I.3. The Science, Business and Policy track's work placement}

Before students start their six-month work placement, they follow a series of preparatory workshops on acquisition tools and career management (i.e., learning to construct proper resumes and application letters, practicing networking and applying for work placements). After successfully completing these workshops, it is the student's responsibility to find and apply for a work placement that fits their academic profile and personal preferences. In accordance with the work placement organisation, students formulate a work placement assignment. This assignment has to contain defined science aspects as well as business or policy aspects and has to result in a science advice report for the client that integrates and bridges theoretical (scientific) and practical (societal) aspects. These final reports have a similar status as a master's thesis - the final (research) report for students who follow a research-track. An advice report is considered to be academically sufficient when it: is based on an integration of scientific knowledge and business or public administration competences; contributes to solving real problems; creates real solutions in society, and; gives practical and implementable advice. During this advising process, the ideal attitude of the SBP-student towards the work placement organisation is to be connected but to stay independent and keep a critical attitude.

During the work placement, the students are supervised by three instructors. First, a daily supervisor at the work placement's organisation is responsible for general supervision. Second, there is a science supervisor from the university who is a specialist on the scientific aspect(s) of the assignment. Third, an SBP-supervisor who is a staff member of the SBPtrack, guards the integration of the different disciplines. During the work placement, all instructors regularly contact the student and each other (i.e., at least once every 2 months).

In addition, there is one week prior to, one week during, and one week after the work placement when students have plenary education at the university:

1. Preparation week: before the work placement, students make an action plan and schedule for their work placement. In addition, students follow lectures on personal development, networking and organisational culture.

2. Midterm week: about 3 months into the work placement, all students - including students with a work placement abroad - return to the university to share experiences, reflect and if necessary, adjust their action plan. 
3. Closing week: after the work placement, all completed work placement advice reports are presented and shared during a three-day symposium visited by all supervisors and other interested parties (e.g., future SBP-students). This week usually couples to a career market where interested parties can meet.

\section{II.1. Theoretical framework of the SBP-track}

This section will outline the theories and models that were used to create the SBP-track and its curriculum. The Bologna Declaration and Social Constructivism as the basis of the overall design of the program are explained. In addition, choices with regard to curricular implementation are described, including the project approach, the loop model, and the business and policy cycle. Furthermore, the learning goals and competences of the SBP-track, based on Bloom's Taxonomy and the Dublin Descriptors, are presented.

From a theoretical perspective, the nature of the SBP-track of positioning science in a societal context, can be considered a contextual approach of learning. The track introduces business and policy concepts to science students, and provides specific tools for application in a work-based situation. This all fits in a model of competence-based learning of contextualized knowledge, inspired by the Bologna Declaration. ${ }^{26,27}$ Individual development in learning is based on additional elements of the SBP-track such as differentiation in disciplinary background and personal preferences to operate in a specific societal context (commercial, governmental or other defined societal interests). Also, personal motivations and qualities may define roles in project management. Together, this asks for a corresponding educational psychology, combined with principles of social constructivism, from which the most important principle is that development takes place by social interaction. ${ }^{28}$

${ }^{26}$ Wagenaar, REFORM!, 191-212.

${ }^{27}$ María José Bezanilla, Ana María García Olalla, Jessica Paños Castro and Manuel Poblete Ruiz, "A model for the evaluation of competence-based learning implementation in higher education institutions: Criteria and indicators," Tuning Journal for Higher Education 6, no. 2 (May 2019): 127-174, http://dx.doi.org/10.18543/tjhe-6(2)-2019pp127-174.

${ }^{28}$ Nicolás Marín, Alicia Benarroch and Jimenez E. Gomez, "What is the relationship between social constructivism and Piagetian constructivism? An analysis of the characteristics of the ideas within both theories," International Journal of Science Education 22, No. 3 (July 2010): 225-238, https://doi.org/10.1080/095006900289840. 
In the SBP-track, a central element aimed at facilitating successfully completing the real-case group projects, and work placement success, is integrating the educational project approach as described by Bos and Harting, ${ }^{29}$ and Bos, Harting and Hesselink.$^{30}$ The project approach focuses on working with project tools, working in project teams, managing the project environment, and personal leadership. This approach is chosen for several reasons. First, the approach provides tools to develop clear time paths and structural elements (e.g., project definition, plan of action and backward planning), as developed by Turner. ${ }^{31}$ Second, running a complete project reflects the expected career path more realistically compared with walking along in existing work (Quality in Work-based Learning). ${ }^{32}$ Third, managing a project creates student involvement, clear attributed achievements, and an active and responsible attitude.

\section{II.1.1. The loop model}

During the work placement, students use different tools (depending on the type and topic of their work placement) and combine these with their disciplinary knowledge and skills, in order to write a sufficiently grounded science advice report. The SBP-track is quite unique and specific, and as such, no science, business and policy knowledge integration tools were available at the time SBP started as a master's track. The SBP-track's staff created its own tool-integration model: the loop model (Figure 3), evolved from a first version developed in 2006 by Gerkema, Van der Windt and Karasek. ${ }^{33},{ }^{34}$ The loop model is based on initial experiences as well as theoretical approaches from the field of science and business and policy

${ }^{29}$ Jo Bos and Ernst Harting, Projectmatig creëren (9 $9^{\text {th }}$ edition) (Schiedam: Scriptum Books, 1998). 2014)

${ }^{30}$ Jo Bos, Ernst Harting and Marlet Hesselink, Project Driven Creation (Utrecht: Phaos,

${ }^{31}$ Rodney J. Turner, The handbook of project based management $\left(2^{\text {th }}\right.$ edition) (London: McGraw-Hill, 1999).

32 "Quality Apprenticeships: A Manual for Educational Organizations Version 1 Eurashe Report Brussels”, ApprenticeshipQ, accessed November 20, 2020, https:// apprenticeshipq.eu/.

${ }^{33}$ Menno Gerkema, Eva Karasek and Henny J. Van der Windt, "Loop model," in Science, Business and Policy Reader, ed. Gert-Jan W. Euverink (Groningen: University of Groningen, 2016).

${ }^{4}$ Menno Gerkema, "Timing and innovation", (Inaugural lecture, University of Groningen, Groningen, 2008). 
integration (e.g., the Triple helix model) ${ }^{35,36}$ The loop model describes a time path from the development of an innovation, starting at an initial idea and resulting in a plan to implement this idea. Often work placement tasks take place within this time path (Figure 3). Sometimes, work placements assignments fit better in loops after the implementation of an idea, for example an evaluation study of a product. In practice, the loop model is adjusted easily to the needs of differently phased projects.

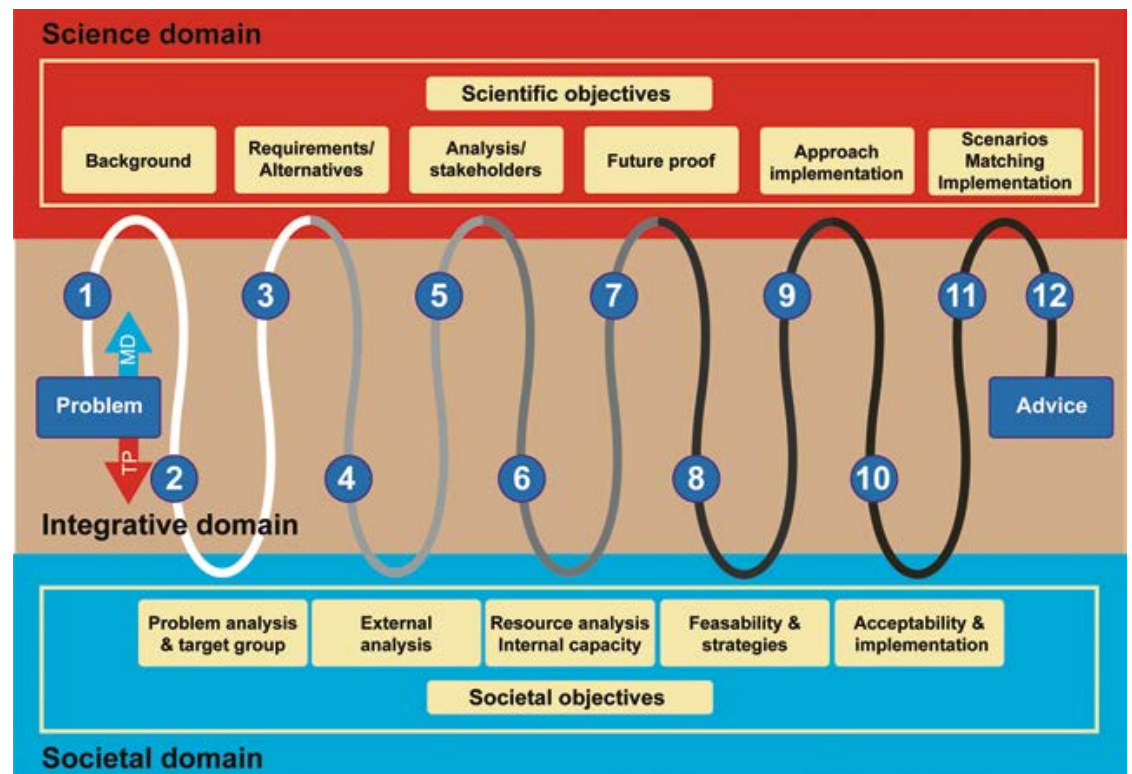

Figure 3

The loop model for integration of the science and technology domain with the societal domain

We explain the loop model from a business work placement perspective here. When a student uses the model for a business work placement, the student

${ }^{35}$ Loet. A. Leydesdorff and Henry Etzkowitz, "The Triple Helix as a model for innovation studies," Science and Public Policy 25, no. 3 (1998): 195-203, https://doi-org.proxy-ub.rug. nl/10.1093/spp/25.3.195.

${ }^{36}$ Loet. A. Leydesdorff and Henry Etzkowitz, "Emergence of a Triple Helix of UniversityIndustry-Government Relations", Science and Public Policy 23, no. 5 (1996): 279-86, https:// www.leydesdorff.net/th1a/. 
starts with a Problem, and determines whether there is a Market Demand problem or a Technology Push. The nature of the problem decides whether the first loop will go up to the science domain, or down to the societal domain. For instance, in case of a market demand problem, the first matter that needs attention is what the current scientific possibilities are. In case of a technology push, the first step is determining whether (individuals in) society could be helped by, or are interested in this technology. The student then follows the loops and connects the science domain and the societal domain within every step. In the loops, several project phases are met. These phases are visible in the picture as numbers. The project phases they can encounter are thus: 1) Initial brainstorm; 2) Question Specification; 3) Problem Definition (concept); 4) Context \& Solution; 5) Threats \& Opportunities; 6) Resource Analysis; 7) Preliminary Conclusion; 8) Embedding; 9) Integration; 10) Action Plan, and; 11) Creating Commitment. During the courses' real case projects, student practice with all these phases by using them in lecture assignments.

The loop model can be adapted for business or policy projects by integrating different tools that are offered and explained to students in corresponding course lectures. In Figure 4, the societal domain of a business loop model, complemented with business tools in the societal domain as compiled from Johnson \& Scholes $^{37}$ is shown.

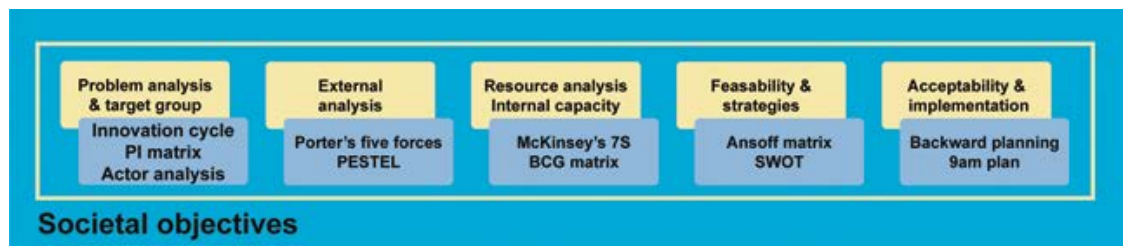

Figure 4

The societal domain of a business loop model, complemented with business tools

II.1.2. The business cycle and policy cycle

Supplementary to placing work placement assignments in the loop model, students have to position their work placement assignment in the

${ }^{37}$ Gerry Johnson and Kevan Scholes, Exploring Corporate Strategy (6 ${ }^{\text {th }}$ Edition) (Edinburgh Gate: Financial Times Prentice Hall, 2002), 1-1070. 


\section{Business innovation cycle}

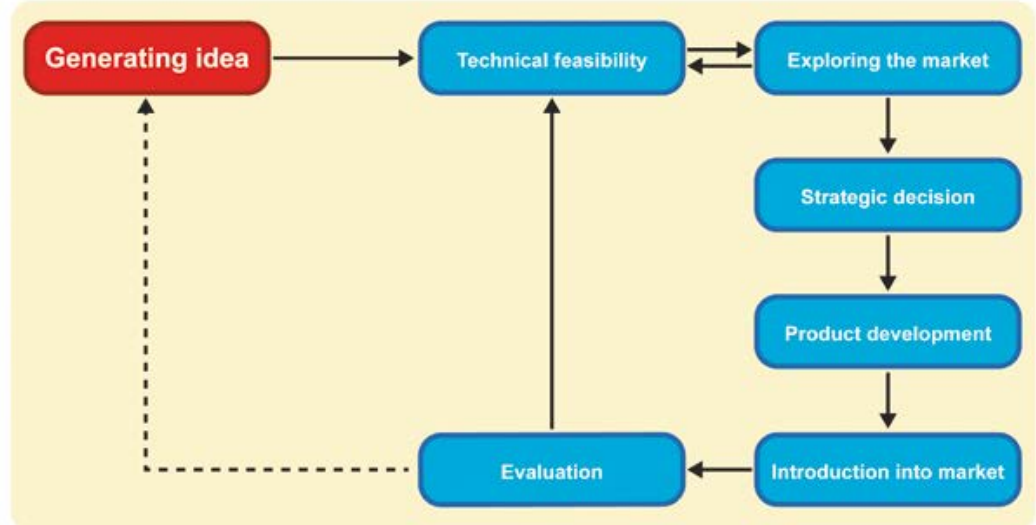

Figure 5

The business innovation cycle as employed in the SBP-track

\section{Policy cycle}



Figure 6

The policy cycle as employed in the SBP-track

business innovation cycle (Figure 5) or policy cycle (Figure 6). In their advice reports, they reflect on the impact of the position their assignment has in the cycle. The science advice can be given at all different stages in a business innovation or policy cycle. Some work placement assignments require advice on multiple stages of the cycle. The cycles have been explained to students during the business and policy courses and they practiced with those cycles during the real case projects. The business innovation cycle is based on the business innovation chain adapted after von 
Stamm ${ }^{38}$ and Conway \& Steward. ${ }^{39}$ The cyclical approach is familiar to students as they have worked with the empirical cycle ${ }^{40}$ in research courses and projects during their first master's year. Some of the essential underlying models for the policy cycle are the causal field model, the field process model and the policy tree model ${ }^{41}$ In Figure 6 the cyclic process shown is based on Howard ${ }^{42}$ Hoogerwerf and Herweijer ${ }^{43}$ and Dunn. ${ }^{44}$

\section{II.2. Learning goals and competences}

The learning goals and competences of the SBP-track ${ }^{45}$ are listed in Table 1. Originally, the Bloom taxonomy of general learning objectives ${ }^{46}$ was specified in an academic context in which learning skills address the capacity of independent learning in the so-called Dublin descriptors. ${ }^{47} \mathrm{We}$ translated these descriptors so that they fitted the WBL-approach and included science advising capacities. The prerequisite for science advising is having a certain expertise within a specific science area, in which at least all Bloom objectives and Dublin descriptors have been met. Students learn the

${ }^{38}$ Bettina von Stamm, Managing innovation, design and creativity (Hoboken: John Wiley \& Sons, 2008).

39 Steve Conway and Fred Steward, Managing and Shaping Innovation (Oxford: Oxford University Press, 2009).

${ }^{40}$ Adrianus de Groot, Methodology: Foundations of Inference and Research in the Behavioral Sciences (Belgium: Mouton \& Co, 1969).

${ }^{41}$ Johan. C. Coolsma and André J. G. M van Montfort, "De uitvoering van overheidsbeleid," in Overheidsbeleid, Een inleiding in de beleidswetenschap, ed Andries Hoogerwerf and Michiel Herweijer (Alphen aan den Rijn: Kluwer, 2014), 117-135.

${ }^{42}$ Cosmo Howard, "The policy cycle: A model of post-machiavellian policy making?" Australian Journal of Public Administration 64, no. 3 (September 2005): 3-13, https://doi. org/10.1111/j.1467-8500.2005.00447.x.

${ }^{43}$ Andries Hoogerwerf and Michiel Herweijer, Overheidsbeleid: Een inleiding in de beleidswetenschap (Alphen aan den Rijn: Kluwer, 2014).

${ }^{44}$ William N. Dunn, Public policy analysis: An integrated approach (New York, NY: Routledge, 2018).

45 “Work placement Business and Policy,” University of Groningen, accessed April 09, 2021, https://www.rug.nl/ocasys/fwn/vak/show? code=WMSE901-40.

${ }^{46}$ Benjamin Samuel Bloom, "Taxonomy of educational objectives: the classification of educational goals; Handbook I: Cognitive domain," in Taxonomy of educational objectives: the classification of educational goals; Handbook I: Cognitive domain, ed. M. D. Engelhart, E. J. Furst, W. H. Hill and D. R. Krathwohl (New York: David McKay, 1956), 1-216.

${ }^{47}$ Bologna Working Group, A Framework for Qualifications of the European Higher Education Area. Bologna Working Group Report on Qualifications Frameworks (Copenhagen: Danish Ministry of Science, Technology and Innovation, 2005). 
craft of science advising by additionally studying new knowledge areas concerning technology, business and policy administration, and innovation management. When students combine their scientific expertise with those new knowledge areas, it will lead to an integration of these knowledge domains and the distinction of societal values of science.

In our view, especially the last three learning objectives (4-6, Table 1), which lead to independent learning skills in science advising require additional skills and attitudes that are generally not seen as characteristics of science students. We experience these as being critical for strategic and effective advising and communication, for an entrepreneurial attitude, for leadership and team-playing capacities, and for reflection on the different roles a science student can play in the process of science advising. Together, these six learning objectives are formulated to facilitate an optimal preparation for a successful science advising, with all its specific demands.

Hence, these goals and competences are set up to ensure students are fully prepared for a career in business and/or policy. Furthermore, these learning goals form the basis of the grading criteria. The main element in the final grading of WBL is the science advice report that the SBP-student writes. The SBP-instructor grades this report with a rubric (containing criteria to score the learning goals) and gets input from the daily supervisor and the science instructor. The main difference between the learning goals of research-tracks and the SBP-track is that research-tracks spend additional attention to disciplinary specialization while the SBP-track has an interdisciplinary focus and includes more on general competences. The learning goals did not change over the years (2003-2020).

\section{Table 1}

Learning goals of the Science Business and Policy track

\begin{tabular}{|c|c|}
\hline & Learning Goals \\
\hline \multirow[t]{2}{*}{1} & Getting acquainted with business and policy sciences \\
\hline & $\begin{array}{l}\text { Students are able to write an independent advice with concepts from } \\
\text { business and public administration, innovation management and Science } \\
\text { and Technology studies. }\end{array}$ \\
\hline \multirow[t]{4}{*}{2} & Personal development \\
\hline & Students have the skills to do project work in a group and alone. \\
\hline & $\begin{array}{l}\text { Students are able to show leadership that fits their personality and the } \\
\text { needs of the group. }\end{array}$ \\
\hline & Students have insights in their own strengths and challenges. \\
\hline
\end{tabular}




\begin{tabular}{|c|c|}
\hline & Learning Goals \\
\hline \multirow[t]{3}{*}{3} & Bridging fields of knowledge \\
\hline & $\begin{array}{l}\text { Students are able to understand and to handle business and policy } \\
\text { perspectives. }\end{array}$ \\
\hline & Students are able to create synergy from multiple domains. \\
\hline \multirow[t]{5}{*}{4} & Applications in social context \\
\hline & $\begin{array}{l}\text { Students are able to judge their own discipline critically and in context to } \\
\text { business or policy and society. }\end{array}$ \\
\hline & $\begin{array}{l}\text { Students are able to find a balance between the individual interest and } \\
\text { the group interest. }\end{array}$ \\
\hline & Students are able to act as a science adviser in an ethical way. \\
\hline & Students know how to implement innovations in a sustainable way. \\
\hline \multirow[t]{3}{*}{5} & Effective communication \\
\hline & Students are able to communicate in an effective way to target groups. \\
\hline & Students are able to evaluate their advice so that it is implementable. \\
\hline \multirow[t]{2}{*}{6} & Overall science advising \\
\hline & Students are able to consider their role(s) in science advising critically. \\
\hline
\end{tabular}

\section{Alumni study records analysis}

We describe the development of the student population and the background of 444 science alumni who finished the SBP-track during the first 16 years of its existence. In addition, using a directed content analysis, 289 study records of SBP alumni who graduated between the academic years of 2003/2004-2016/2017 were analysed on several other variables, including work placement characteristics and assignments, source and tool usage during the work placement. Students' grades on theoretical courses and science advice reports were explored for the academic years 2015/20162019/2020.

For each of the variables examined in this case study, we formulate what exactly we will examine, including potential outcome expectations:

1. Student population and background: we will examine how students are divided over the different science disciplines within the SBPtrack. It is expected that biomedical science students form the largest 
group, since this is also the largest program within the faculty. Furthermore, biology students could be strongly represented because the origin of the SBP-track lies in biology. In principle, we expect the total population of students to grow due to increasing interest. This increased interest is not expected to be reflected reliably due to capacity limitations of the SBP-track. However, if the program is in line with the demand of society and the interest of the students, we would expect an overall increase in the number of students.

2. Work placement characteristics: we will study the distribution of the work placements' type, size, location and sector. We expect sector to correspond with student's academic background. In addition, we expect all characteristics to also correspond with personal preferences (i.e., due to the design of the program students may arrange their own placement), without a specific expectation of which is the most common.

3. Work placement assignments: we will analyse the distribution of the work placements' type of assignment, and stage of the innovation cycle and policy cycle it relates to. On one hand we expect an emphasis on the scientific aspects because this is in line with the paradigm of the science students (after four years of full focus on science during their studies). On the other hand: the type of assignment and position in the cycles depend on the requirements of the work placement. Hence, placements outside the loop model are also expected since stages from the innovation cycle that focus on execution, implementation and evaluation (see Figure 5) also occur in the workplace. No specific expectations are formulated for which type of assignment occurs most.

4. Source usage: we will examine how many literature references and external contacts students cite in their advice report. Since all SBPstudents are at the end (i.e., last year) of their master's program, you expect a proficiency in literature search use and thereby adequate and sufficient references to scientific literature. Although science students are generally not trained in the use of external contacts as a source, SBP-students are during SBP-courses. That is why we also expect that students will be less reluctant to refer to at least some external contacts per placement. Given the large number of stakeholders in policy issues ${ }^{48}$ we expect more references to external contacts in policy placements than in business placements.

${ }^{48}$ Dirk-Jan F. Kamann, Externe Organisatie: een inleiding vanuit een netwerkperspectief (Groningen: Charlotte Heymanns Publishers, 2003), 1-301. 
5. Business, policy and loop model tools (absolute frequency): at the SBP-track, a variety of tools is offered, and we expect that the use of these tools fits the individual work placement and therefore will be very diverse. We also expect students to use the loop model but not every loop in every stage, as the work placement assignments can focus on one specific loop or a limited number of loops.

6. Work placement, business and policy grades: for the grade analysis, students' grades on business and policy courses, and business and policy work placements are correlated, to measure the relationship between theory and practice for both business and policy courses and their corresponding work placements. We expect business theory grades to correlate positively with business work placement and policy theory grades to correlate positively with policy work placements. Lastly, assuming an ideal situation, we expect the business theory grades to correlate most positively and highly with business placements and the policy theory grades to correlate most positively and highly with the policy placements.

\section{Methodology}

For investigating student background, data of all students who followed the SBP-track between the academic years 2003/2004-2019/2020 were employed. For investigating study records, data were extracted from the archive of the SBP-track, that contained study records of all SBP-students finishing a work placement between the academic years 2003/2004 2016/2017 (for these years we had complete records to our disposal). Study records included SBP-students' reports and grades, which served as units of analysis. For the grading analysis, only grade data between the academic years 2015/2016-2019/2020 were used, as grading practices were revised after 2014/2015. Before 2015/2016, students received a combined grade for business and policy, making it unable to measure the relationship between a business or policy course grade with a business or policy work placement.

\section{IV.1. Analysis of advice reports}

A directed content analysis (DCA) was carried out to analyse the science advice reports of the SBP-students. This implies that a predominant deductive approach was applied in analysing the data while allowing for an inductive 
approach. Before the coding process, student names were replaced with student numbers to guarantee confidentiality. The variables being examined, as well as their categories, were predefined to the furthest extent possible before analysis. However, whenever data were associated with a certain variable but did not fit into a predefined coding category, the data were stored and in a later stadium coded inductively. An important advantage of DCA over a purely inductive thematic analysis is that DCA contributes more explicitly to theory formation. DCA allows researchers to concentrate on parallels or deviations with existing theory and are less likely to 'drown' in the details of the data: DCA brings focus. ${ }^{49,50}$

All topics coding categories were categorical or binary in nature and were - before, during and after analysis - checked for mutually exclusiveness. The reports were examined by coders on the presence of coding categories, which were recognized by the inclusion of specific words or phrases (e.g., 'Biology' for 'Student background), and theoretically formulated themes (e.g., 'Exploring the market' for 'Position in stages of business cycle') in the reports. For the first type of coding, coders exclusively relied on the presence of specific words/ phrases. For the latter type of coding, interpretation was needed to translate the data into a coding category and in some cases to inductively add new categories.

While the authors of the paper acknowledge that predetermined coding categories can bias analysis in favour of certain theories ${ }^{51}$ they are confident that in the context of this study, the initial coding will not affect the recognition of important content due to the nature of the data and the theoretical framework employed. That is, the theoretically formulated themes and coding categories match the theoretical framework students had to employ in their science advice reports.

\section{IV.2. Procedure}

All coding topics and their categories were collected in a codebook, which served as a coding guide for the coders. Table 2 shows an example of the manner in which topics and categories were explicated in the codebook

49 AnneLoes van Staa and Kirsten de Vries, "Directed content analysis: een meer deductieve dan inductieve aanpak bij kwalitatieve analyse." KWALON 19, no 3 (May 2016): 46-50.

${ }^{50}$ Hsiu-Fang Hsieh and Sarah Shannon, "Three Approaches to Qualitative Content Analysis." Qualitative health research 15, no. 9 (December 2005): 1281-83, https://doi. org/10.1177/1049732305276687.

${ }^{51}$ Hsieh and Shannon, "Three Approaches to Qualitative Content Analysis,” 1283. 
for two variables: 'Work placement size' and 'Position in stages of the policy cycle'. The codebook included for each variable its coding categories, howto-code coding explanations, as well as references to articles and/or documents from which the categories/explanations were extracted. For the full codebook, the reader is referred to Appendix A.

Three student-assistants, which were SBP-students, coded the data together under the supervision of the authors of this paper. It was a deliberate choice to appoint SBP-students as coders. Because the coders had theoretical knowledge about the theories involved in this study, less intensive coder training was necessary to become an adequate coder. In addition, having SBP-students as coders may have improved the coding quality as it is reasonable to assume that having knowledge about the program makes coding more straightforward, evident and reliable in the context of this study. Because coding topics and corresponding categories were primarily predetermined, potential coder bias resulting from being familiar with SBP was minimalized. Still, it is recognized that the coders were students with a science background who were not familiar with quantitative nor qualitative coding practices, which are often carried out by researchers from social sciences. Therefore, before, during and after coding a research-assistant with experience in coding was available for additional training and consultation.

\section{Table 2}

Codebook example for work placement size, and position in policy cycle

\begin{tabular}{|c|c|c|}
\hline Variable & Code & Explanation \\
\hline $\begin{array}{l}\text { Work } \\
\text { placement } \\
\text { size }\end{array}$ & $1,2,3,4$ &  \\
\hline
\end{tabular}




\begin{tabular}{|c|c|c|}
\hline Variable & Code & Explanation \\
\hline $\begin{array}{l}\text { Position in } \\
\text { stages of } \\
\text { the policy } \\
\text { cycle }\end{array}$ & $\begin{array}{c}1,2,3,4,5,6 . \\
\& \\
0,1\end{array}$ & $\begin{array}{l}\text { This variable needs to be scored only for science } \\
\text { advice reports that were written in the context of a } \\
\text { policy work placement. There are six categories in } \\
\text { the policy cycle. These categories are referred to as } \\
\text { position in stages in the policy cycle. Within a policy } \\
\text { work placement science advice report, multiple stages } \\
\text { can be mentioned and treated as such by the student. } \\
1=\text { Setting the agenda } \\
2=\text { Problem analysis } \\
3=\text { Design } \\
4=\text { Stipulation } \\
5=\text { Execution } \\
6=\text { Evaluation } \\
\text { Decide for each chain whether or not it is: a) } \\
\text { mentioned explicitly, and; b) explained correctly by } \\
\text { the student. } \\
0=\text { no, } 1=\text { yes. } \\
\text { Only score } 1 \text { when both condition a) and b) are } \\
\text { met. The policy cycle and its chains are based on } \\
\text { Howard }{ }^{52} \text {, Hoogerwerf \& Herweijer }{ }^{53} \text {, and Dunn }{ }^{54} \text {. }\end{array}$ \\
\hline
\end{tabular}

Whenever the coders disagreed about which coding categories the data should be assigned to, or were in doubt whether certain coding categories fitted the data correctly, one of the supervisors was consulted. Based on deliberation between this supervisor and two coders, coding categories were assigned to data or data were coded inductively. The coders coded the data during ongoing collaboration and calibration.

\section{Results}

\section{V.1. Student population and background}

In this paragraph, the student populations within the faculty and SBPstudents' backgrounds are outlined to document the interest in the track over

${ }^{52}$ Commission of the European Communities, "Commission Recommendation of 6 May 2003 concerning the definition of micro, small and Medium-sized enterprises, 36-41. Howard, "The policy cycle", 3-13.

${ }_{53}$ Hoogerwerf and Herweijer, Overheidsbeleid.

${ }^{54}$ Dunn, Public policy analysis. 
the subsequent academic years, as well as the choice for the track, differentiated for the student's prior discipline. Because of the varying science backgrounds of the SBP-students we related the choice for the SBPtrack to the total cohort numbers of students in the various disciplines.

In total, 444 students completed the SBP-track, starting their work placements between 2003/2004 and 2019/2020 (Figure 7). Subscription numbers have increased over time. In 2017/2018 and 2018/2019 the course program was fully enrolled (a capacity of 65 places). Some students signed in for only a single course in 2017/2018 and 2018/2019, resulting in a lower number (i.e., <65) of students completing the SBP-track. In the academic year 2019/2020, all places in the SBP-track were completely filled. Currently, there is a waiting list to enrol in the SBP-track.

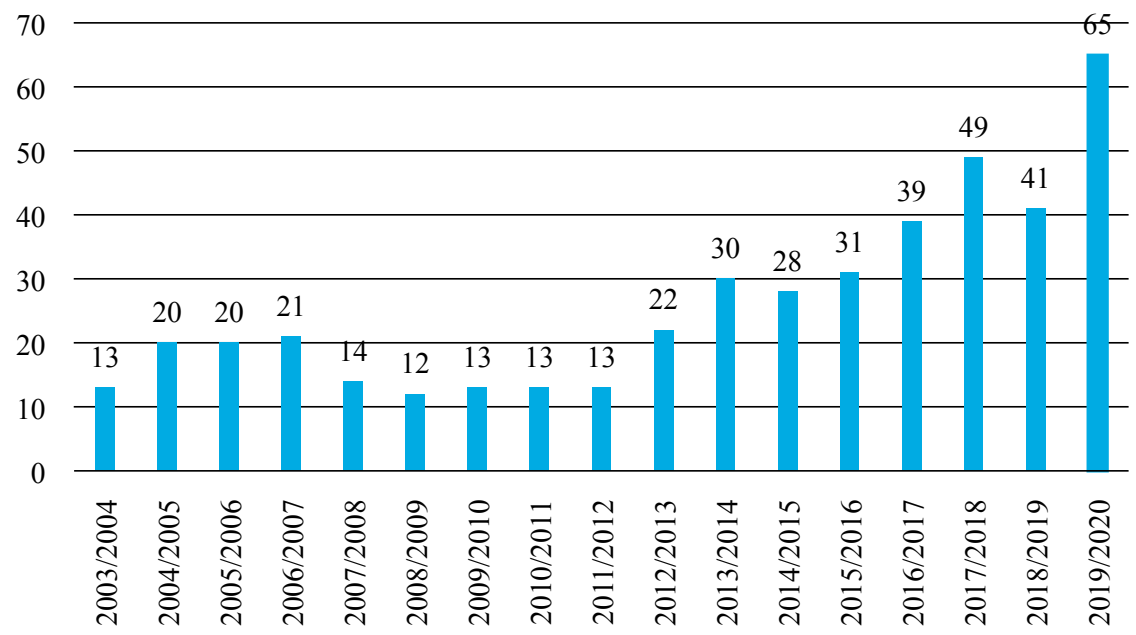

Figure 7

Number of SBP-students per academic year, 2003/2004-2019/2020, $\mathrm{N}_{\text {total }}=444$

The scientific backgrounds of the students vary. All SBP-students are science students enrolled at the faculty of Science and Engineering. Engineering students are excluded from the SBP-track. The studies that are (or have been) compatible with the SBP-track are Chemistry, Physics, Computing Science, Mathematics, Molecular Biology \& Biotechnology, Medical Pharmaceutical Sciences, Marine Biology/Ecology \& Evolution, Biology, Biomedical Sciences, Energy \& Environmental sciences (for the 
latter, enrolment is possible since 2019) and Behavioural \& Cognitive Neurosciences (but not within a specific research master). Results show that the largest fraction of SBP-students has a science background in Biomedical Sciences and Biology (Figure 8).

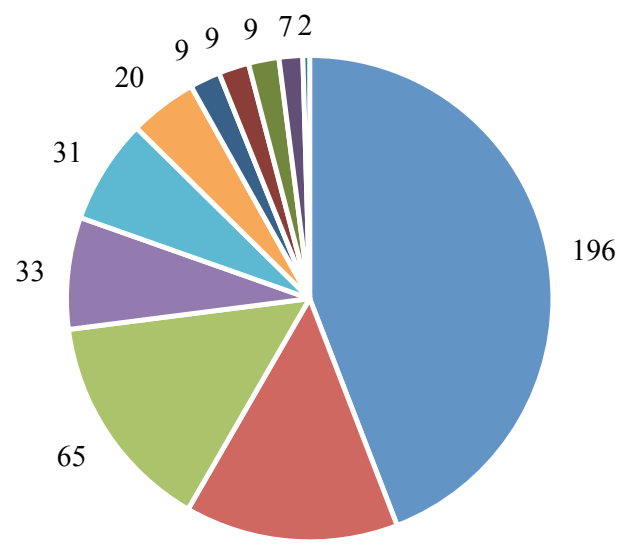

63

- Biomedical sciences

- Marine biology, ecology \& evolution

- Moleculair biology \& biotechnology

- Energy \& environmental sciences

- Chemistry

- Computing sciences
- Biology

- Medical pharmaceutical sciences

- Mathematics

- Behavioural \& cognitive neurosciences

- Physics

\section{Figure 8}

SBP-students' disciplinary background 2003/2004-2019/2020, $\mathrm{N}_{\text {total }}=444$

The number of students in the studies that form the background of SBPstudents differ in size. Science students choosing SBP make up between $2-11 \%$ of the entire science student population at the University of Groningen between 2003/2004-2019/2020. The remainder of science students choose a research-, or educational-oriented master's track (89-98\%).

Figure 9 shows for each disciplinary background the percentage of students choosing SBP after their first master's year. Physics students and Computing Science students only occasionally choose SBP. Looking at the 
relative numbers compared to the total amount of students in a track, Biology, Biomedical Science students and Marine Biology students choose SBP most often. Physics is more oriented on fundamental research then other FSE programs and Computing Science is mainly focused on programming. These students may not associate their future career immediately with business or policy. As such, SBP may seem a less logical choice for those students at first sight. Conversely, Biology, Biomedical Sciences and Marine Biology are fields more oriented on knowledge appliance in society. As such, SBP might be more popular among those studying in these fields.

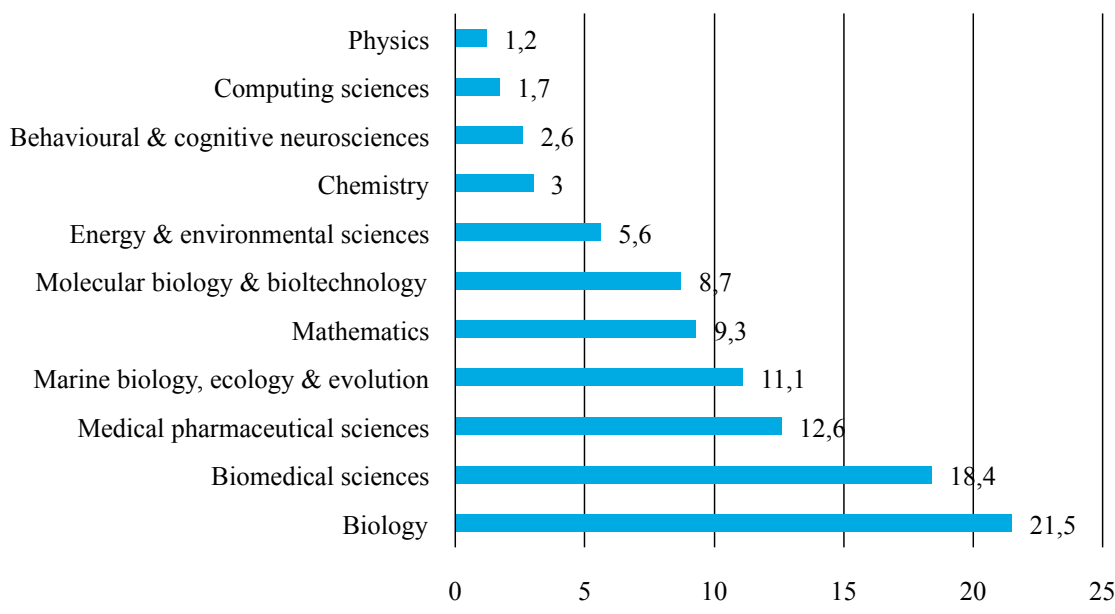

Figure 9

Percentage of the total disciplinary cohort of science students choosing SBP per background, 2003/2004-2019/2020

\section{V.2. Work placement characteristics}

Figure 10 A-D shows several work placement characteristics, including type, size, sector and location. Figure 10A shows that more than half of the 289 work placements analysed took place in a commercial setting: business placements make up 57\% of all work placements. Policy work placements are the most common work placement after business placements: $38 \%$ of all students choose a work placement in a policy context. A minority of the students, $5 \%$, have a NGO work placement. 
About half of the work placements take place in organisations with 250 employees or more (Figure 10B). The other half takes place in small-, to medium-sized organisations, or $\mathrm{SME}^{55}$, where the number of employees of $14,2 \%$ of the placements are in micro (1-9 employees), $21.1 \%$ in small (1049 employees) and $13.5 \%$ in medium (49-249 employees) size enterprises or organisations.

The sector work placements most often take place in are healthcare \& pharmacy and agriculture \& environment (Figure 10C).

Focusing on geography, more than half of the SBP-students (57.4\%) stay in the North of the Netherlands (Provinces of Groningen, Friesland and Drenthe). About $5 \%$ of the students choose a work placement in a foreign country (Figure 10D).

\section{A: Work placement type}



${ }^{55}$ Commission of the European Communities, "Commission Recommendation of 6 May 2003 concerning the definition of micro, small and Medium-sized enterprises," Official Journal L 124 (May 2003): 36-41, http://data.europa.eu/eli/reco/2003/361/oj. 


\section{B: Work placement size}

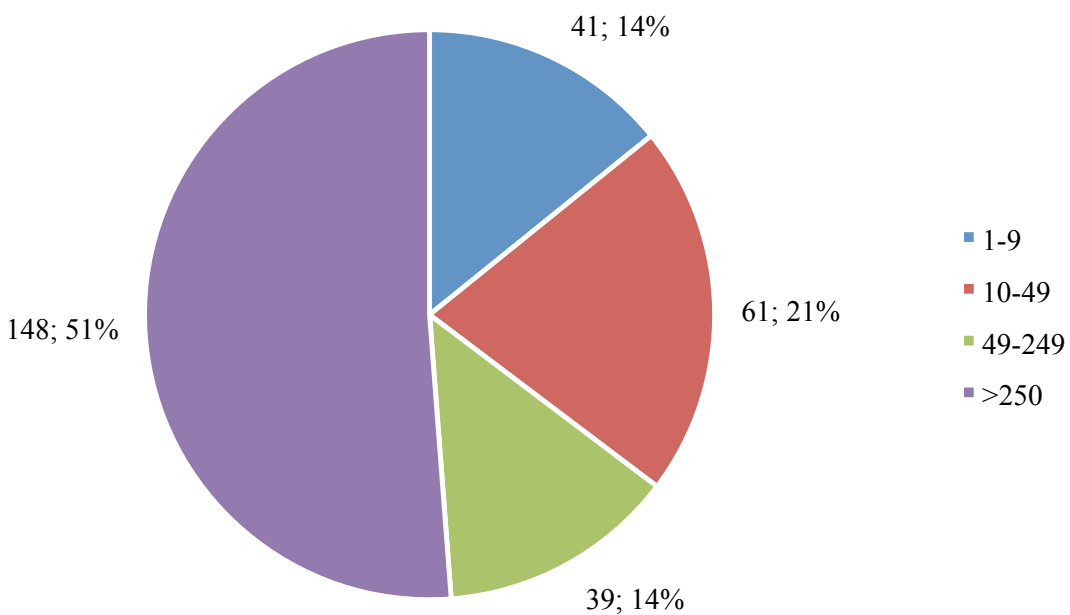

C: Work placement sector



$24 \%$ 


\section{D: Work placement location}

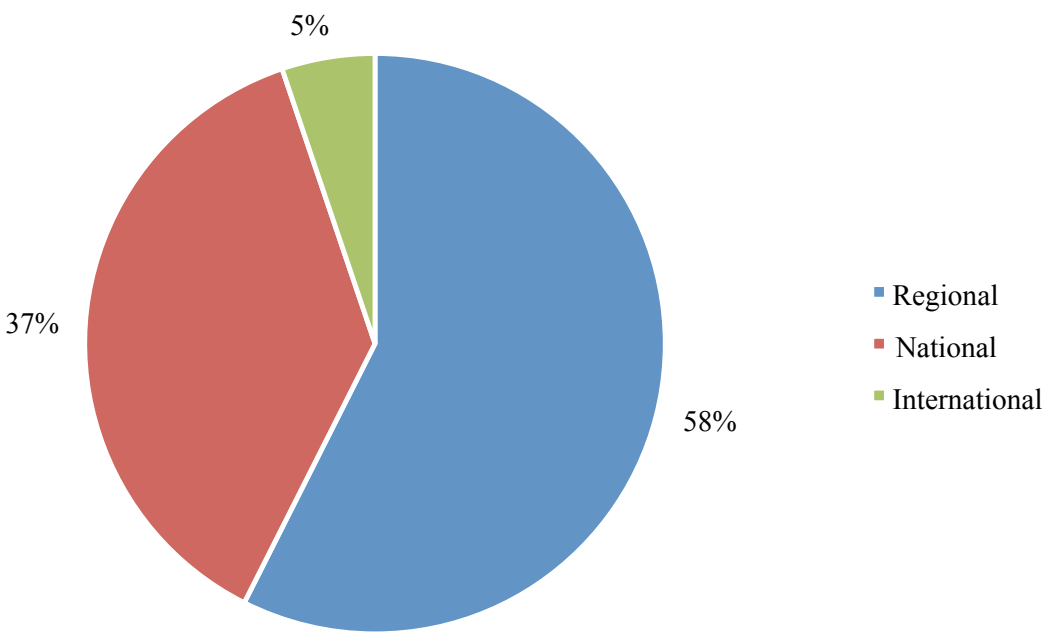

Figure 10A-D

Work placement characteristics, 2003/2004-2016/2017, $\mathrm{N}_{\text {total }}=289$

\section{V.3. Type of work placement assignment \& position in stage of cycles}

The different types of assignments extracted from the content analysis of the executive summary of the science advice reports are shown in Figure 11. The most frequent types of assignments were implementation, feasibility evaluation, product/policy evaluation and market research advice. Communication strategy, organisational structure and market demand advice were included in the reports least frequently. In total, 336 types of assignments were present in 289 reports, implying combined use of types of assignments.

Besides the type of assignment, the position in the stage of the advices also varied. When placed in the business innovation cycle (Figure 12) or policy cycle (Figure 13), we see that most work placements with a business assignment are in the stage of analysing technical feasibility or market exploration. The policy placements are most commonly in the problem analysis or design and formulation stage. 
Implementation

Feasibility evaluation

Product evaluation

Market research

Communication strategy

Organisational structure

Market demand



Figure 11

Type of work placement assignment, 2003/2004-2016/2017,

$\mathrm{N}_{\text {assignments }}=336, \mathrm{~N}_{\text {students }}=289$

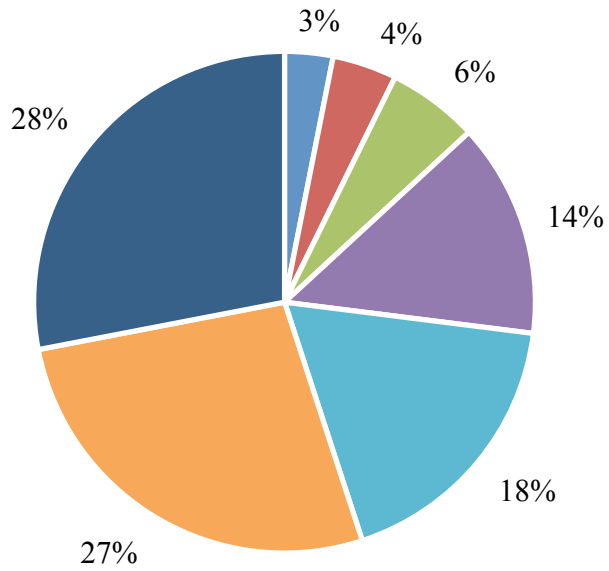

- Generating idea

- Evaluation

- Introduction to market

- Product development

- Strategic decision

- Exploring the market

- Technical feasibility

Figure 12

Position of stages in the business innovation cycle, 2003/2004-2016/2017,

$\mathrm{N}_{\text {business students }}=165, \mathrm{~N}_{\text {business innovation cycle stages }}=289$ 




Figure 13

Position of stages in the policy cycle, 2003/2004-2016/2017,

$\mathrm{N}_{\text {policy students }}=124, \mathrm{~N}_{\text {policy cycle stages }}=166$

\section{V.4. Source usage}

In work placement reports between 2003/2004-2016/2017, 289 students cited 25140 literature references, which reflects an average of 87 per student. Besides (scientific) articles, students used other sources for information, for example collecting information by conducting expert interviews. It should be noted here explicitly that because SBP-students do not carry out their own conclusive scientific research during a work placement, they use external information sources only.

When external contacts explicitly had impact on the final result students had to report these sources in their advice report (e.g., an interview transcript added to an appendix). Figure 14 shows the number of external contacts used as information source. In total 1528 contacts were used, with an average of 5,3 per work placement. Most external contacts were used as information sources in work placements at NGO's, followed by policy placements, with the least input from external contacts at business placements. 


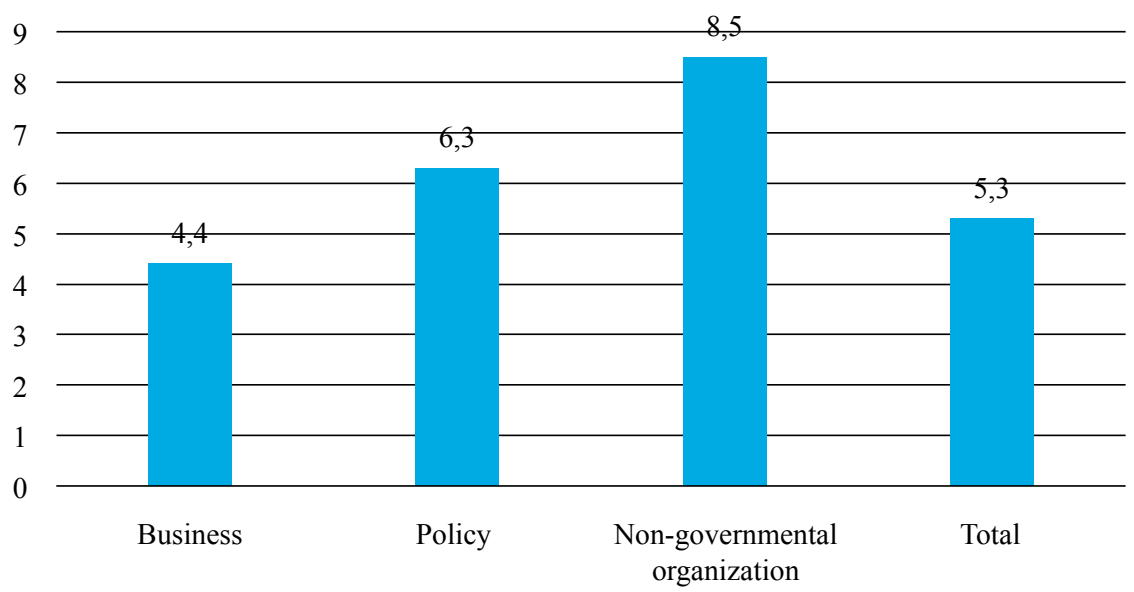

Figure 14

Means of references to external contacts per work placement type, 2003/2004-2016/2017, $\mathrm{N}_{\text {students }}=289$

\section{V.5. Business and Policy tools}

Business and policy tools that were employed in work placements were scored. The scored models were those explicitly taught in the lectures during the preceding courses (see for example Figure 7). In the policy related placements (Number of students $=124$ ) the most frequently used tools are stakeholder analysis $(\mathrm{N}=50)$, the SWOT analysis $(\mathrm{N}=17)$ mapping of the organisation culture $(\mathrm{N}=15)$, and internal analysis $(\mathrm{N}=15)$. In the business placements, a more differentiated use of models could be observed. Table 3 shows the absolute frequency of tools used by the students in a business work placement.

\section{Table 3}

Frequency of tools used in business work placements, 2003/2004-2016/2017, $N_{\text {students }}=165$

\begin{tabular}{|l|c|}
\hline \multicolumn{1}{|c|}{ Tool } & Frequency business placements \\
\hline SWOT analysis & 69 \\
\hline Internal analysis (general) & 58 \\
\hline Porter's 5 forces & 52 \\
\hline
\end{tabular}




\begin{tabular}{|l|c|}
\hline \multicolumn{1}{|c|}{ Tool } & Frequency business placements \\
\hline Organisation structure & 39 \\
\hline PESTEL & 33 \\
\hline External analysis (general) & 30 \\
\hline Stakeholders/actors & 28 \\
\hline 7S model & 27 \\
\hline MCCBA / cost-benefit & 19 \\
\hline Ansoff matrix & 3 \\
\hline Business model canvas & 2 \\
\hline Goal-resource analysis & 2 \\
\hline BCG-matrix & 2 \\
\hline Technology adoption lifecycle & 1 \\
\hline Market share matrix & 1 \\
\hline Customer buying cycle & 1 \\
\hline Product life cycle & 1 \\
\hline Total & 368 \\
\hline
\end{tabular}

\section{V.6. Tools in loop model}

In Table 4, the relative number of students who used at least one model in the loop is shown. The loops that are most often covered are loop $3(61,2 \%)$ and $2(51,5 \%)$. Loop 5 has not been scored because the SBP-track had not fully standardized the use of tools denoting implementation in earlier years.

\section{Table 4}

Relative frequency of tools used in business placements per loop in the societal domain of the loop model, 2003/2004-2016/2017, $\mathrm{N}_{\text {students }}=165$

\begin{tabular}{|l|l|c|}
\hline \multicolumn{1}{|c|}{$\begin{array}{c}\text { Loops societal } \\
\text { domain }\end{array}$} & \multicolumn{1}{|c|}{ Tools } & $\begin{array}{c}\text { Percentage of } \\
\text { students using at } \\
\text { least one tool }\end{array}$ \\
\hline $\begin{array}{l}\text { Problem analysis \& } \\
\text { target Group }\end{array}$ & $\begin{array}{l}\text { causal/fieldmodel, stakeholders/actors, } \\
\text { Goal-resource analysis, Technology } \\
\text { adoption lifecycle, customer buying } \\
\text { cycle, product life cycle }\end{array}$ & $27.9 \%$ \\
\hline
\end{tabular}




\begin{tabular}{|l|l|c|}
\hline \multicolumn{1}{|c|}{$\begin{array}{c}\text { Loops societal } \\
\text { domain }\end{array}$} & \multicolumn{1}{|c|}{ Tools } & $\begin{array}{c}\text { Percentage of } \\
\text { students using at } \\
\text { least one tool }\end{array}$ \\
\hline External analysis & $\begin{array}{l}\text { PESTEL, Porter's 5 forces, External } \\
\text { analysis (general) }\end{array}$ & $51.5 \%$ \\
\hline $\begin{array}{l}\text { Resource analysis \& } \\
\text { Internal capacity }\end{array}$ & $\begin{array}{l}\text { 7S, Internal, BCG-matrix, organisation } \\
\text { structure }\end{array}$ & $61.2 \%$ \\
\hline $\begin{array}{l}\text { Feasibility \& } \\
\text { Strategy }\end{array}$ & $\begin{array}{l}\text { SWOT, business model canvas, MCCBA/ } \\
\text { cost-benefit, ansoff matrix, market } \\
\text { share matrix }\end{array}$ & $48.5 \%$ \\
\hline $\begin{array}{l}\text { Acceptability \& } \\
\text { Implementation }\end{array}$ & n.a. & - \\
\hline
\end{tabular}

\section{V.7. Grades}

Table 5 shows the correlations, means and standard deviations for final exams and work placement grades (1-10 scale) of all SBP-students. All grades are positively and significantly correlated with each other. Business and policy exam grades (theory) are more strongly related than work placements grades to either business or policy exam grades. The mean grades are all above average and are scored on a 1-10 scale (pass at $5,5)$.

Table 6 shows the correlations, means and standard deviations for grades of SBP-students with a business work placement. All grades are positively and significantly correlated. The business work placements grades are more strongly and positively related to business grades than business work placements grades are related to policy grades.

Table 7 shows the correlations, means and standard deviations for grades of SBP-students with a policy work placement. All grades are positively and significantly correlated. The policy work placements grades are more strongly and positively related to policy grades than policy work placements grades are related to business grades. Policy work placements grades are more strongly related to policy grades than business work placements grades are related to business grades.

While policy exam grades seem lower than the business exam grades, and both the business and policy exam grades seem lower than the work placement grades, a multivariate ANOVA showed that there are no significant differences between business theory, policy theory and work placement grades. 
Table 5

Descriptive statistics: correlation, means and standard deviations of student grades of all placements, 2015/2016-2019/2020, $\mathrm{N}_{\text {students }}=188$

\begin{tabular}{|l|c|c|c|c|}
\hline \multicolumn{1}{|c|}{ All work placements } & Grade Theory Business & Grade Theory Policy & M Total & SD \\
\hline Grade work placement & $.299 * *(p=.000)$ & $.355^{* *}(p=.000)$ & 7.60 & .70 \\
\hline Grade Theory Business & - & $.542 * *(p=.000)$ & 7.30 & .93 \\
\hline Grade Theory Policy & & - & 6.91 & 1.00 \\
\hline
\end{tabular}

$* p=<.05 ; * * p=<.001$.

Table 6

Descriptive statistics: correlation, means and standard deviations of student grades of all business placements, 2015-2019, $\mathrm{N}_{\text {students }}=111$

\begin{tabular}{|l|c|c|c|c|}
\hline \multicolumn{1}{|c|}{$\begin{array}{c}\text { Work placement } \\
\text { Business }\end{array}$} & Grade Theory Business & Grade Theory Policy & $\begin{array}{c}\text { M } \\
\text { Business }\end{array}$ & SD \\
\hline Grade work placement & $.326 * *(p=.001)$ & $.299 * *(p=.001)$ & 7.59 & .76 \\
\hline Grade Theory Business & - & $.538 * *(p=.000)$ & 7.25 & .93 \\
\hline Grade Theory Policy & - & 6.85 & .88 \\
\hline
\end{tabular}

$* p=<.05 ; * * p=<.001$.

Table 7

Descriptive statistics: correlation, means and standard deviations of student grades of all policy placements, 2015-2019, $\mathrm{N}_{\text {students }}=77$

\begin{tabular}{|l|c|c|c|c|}
\hline Work placement = Policy & Grade Theory Business & Grade Theory Policy & M Policy & SD \\
\hline Grade work placement & $.251^{*}(p=.030)$ & $.462 * *(p=.000)$ & 7.62 & .62 \\
\hline Grade Theory Business & - & $.555^{* *}(p=.000)$ & 7.36 & .92 \\
\hline Grade Theory Policy & & - & 6.99 & 1.15 \\
\hline
\end{tabular}

$* p=<.05 ; * * p=<.001$.

\section{Retrospect, conclusion \& discussion}

In this paper, we described a case study of an academic (university level 7) work-based learning (WBL) master's program. This WBL-program, the Science, Business and Policy (SBP) track, is offered at a Dutch research 
university at the faculty of science and engineering. The track is developed to prepare science students for a science career in business or policy, and is a direct response to the Bologna Process (i.e., a reform of European education), serving as an alternative for a traditional research master's track. The SBPtrack offers societal differentiation by including a work placement at a business or policy organisation and a focus on science advising, as opposed to a research track, that mainly includes theoretical courses and has a strong research focus.

A major aim of this paper was to explain the build-up of, and the reasoning behind this WBL-program, including the explanation of the theoretical framework used to develop the SBP-track, as well as laying out the learning goals and tools derived from these frameworks. In addition, alumni records of the SBP-track from 2003-2019 were analysed, on student population and background, work placement characteristics and assignments, source and tools usage and grades for theoretical courses and work placements. The results of this case study indicate that several factors can be seen as relevant for a successful elaboration of an academic WBL-program.

\section{VI.1. Design and curriculum}

In our view, six important factors can be distinguished that put emphasis on the success of SBP as a WBL example, due to its design of the curriculum. First, the SBP-track was specifically designed to function as a WBLprogram, created by academics for academics, as a formal reaction to the Bologna process. This makes that the program has an explicit focus on narrowing the gap between the scientific and the professional field without compromising on the academic level and constantly monitoring this.

Second, the SBP-track is offered completely within the curriculum of a research university (level 7) science masters' and students receive the full amount of ECTS (120 ECTS) necessary to graduate. That is, the SBP-track fits in the typical two-year structure of science master's programs in the Netherlands. The SBP-track's courses (20 ECTS) and work placement (40 ECTS) are offered completely and exclusively within the curriculum. This creates the possibility for students to focus and gain substantial theoretical and scientific knowledge based on specialized disciplinary research in a first master's year (60 ECTS) and a focus on experience outside academia (60 ECTS) in a second (SBP) master's year. The efficiency of the work placements is enhanced by staff specifically devoted to the SBP-track, who support students in arranging and preparing work placements, reviewing during work placements, and evaluating after work placements. 
Third, strict starting requirements, including a sufficient academic level and intensive disciplinary knowledge at entrée (i.e., a pass on a first master's year disciplinary thesis) contributes to the quality of the SBP-track. On the same note, students have to pass their business and policy courses before they are allowed to start the work placement. As a result, students normally do not fail their work placements (spare exceptions due to personal circumstances). Hence, a basis for an academic performance is given, since a previously completed master's thesis in research and a pass for the business and policy courses are required to start the work placement.

Fourth, the project approach that forms the core of the SBP-track facilitates students to fully engage in high-quality work-based learning, for instance by studying real-world topics in academic courses and practicing real-world topics through solving existing (i.e., real) problems during the work placements. To make students connect with prior academic knowledge, models that are similar to models already familiar to students (e.g., the empirical cycle of science) are used to approach policy and business (i.e., the loop model, the business innovation cycle and the policy cycle) during the SBP master's year. These models are specifically tailored to serve the practical goals of the SBP-track, along with supporting the academic level of SBP. That is, these models, based on academic literature, establish a broad theoretical framework for SBP-students.

Fifth, while the SBP-track does include theoretical courses in its curriculum, its main focus lies on the integration and implementation of knowledge. The SBP-track is designed to lead to integration at three levels: between different science disciplines, between science and business/science and policy, and academia and the professional work field ("town and gown"). This fulfils the criteria of WBL that theory is necessary, yet the main component should be learning in real life practice. The threefold integration within SBP seems important to match the requirements of the present-day career that education is interdisciplinary, practical applicable and competencebased. That is, there is a need to match the criteria of an academic educational institute with the ability to offer education that can be tailored to individual students, enhances critical thinking and meets the academic level. ${ }^{56}$ The SBP-track meets this academic level, and combines it with a systematic integration of complex information and gaining experience in the work field.

Sixth, the strength of the SBP-track originates in the appliance of learning objectives that are specifically formulated to match the WBL educational method in academia. These learning objectives are developed to

${ }^{56}$ Lester and Costley, "Work-based learning at higher education level," 570-572. 
let students achieve a common and generic academic final level. Within the university, the learning objectives have often been evaluated in recent years, with all parties involved - including business and policy experts. Perhaps surprising, in the course of 15 years teaching SBP there has never been risen a need for adjustment. The learning goals seem to still fit the requirements of academic WBL-practice.

Hence, based on these six factors, the SBP-track - as well as other properly-designed academic WBL-programs - can thrive well within the Bologna Declaration. A WBL-program is in this sense able to narrow the gap between academia and the professional work field without compromising on academic level.

\section{VI.2. Alumni study records}

SBP-students' study records were explored for purposes of determining possible factors for quality and success of WBL-programs, as well as for retaining more comparable information on academic WBL-programs. First, exploration of the student population throughout the years, including student backgrounds showed that the SBP-track attracts a growing number of students, many of them having a background in biomedical sciences and biology. In total, 444 students followed the full track between 2003/20042019/2020. An increasing number of students is opting to spend their final master's year on SBP. From 2016/2017 to 2019/2020, the SBP-track's capacity has been fully booked. The actual demand is difficult to extract from the growth numbers since the program has a restricted intake capacity due to practical limitations. Still, it is becoming an increasingly common practice that potential new students are waitlisted for at least one year.

As the founders of the SBP-track intended, the results show that the SBPstudent population is multidisciplinary. The largest cohorts are from biology and biomedical sciences. This is representative for the whole faculty, as biology and biomedical sciences form the largest science master's programs. In our personal experience the awareness of the existence of the SBP-track varied - and may still vary - between the disciplinary programs. In addition, it has to be mentioned that the amount of promotion made for the SBP-track between staff members from different disciplines varied - and may still vary - as well. Still, the enhanced interest of students from different disciplines within science in this societal WBL-program is noticeable. Growing student numbers from increasingly different disciplines may be an indication for the quality and success of the SBP-track. 
Second, several characteristics of student's work placements were analysed, including type, size, location and sector of the work placement. These characteristics show quite a diversity of work placement characteristics, but also some trends. Based on work placement type and size, there are indications that smaller as well as larger organisations in the corporate world can benefit from the interest of SBP-students. For instance, more than half of SBP-students choose a business type work placement, and more than half choose a work placement organisation with more than 250 employees.

In addition, over half of all work placements take place in the North of the Netherlands, where the University of Groningen is situated. This finding seems somewhat remarkable because in the northern region of the Netherlands there are less large employers compared to the rest of the Netherlands. However, cities in Northern Netherlands, e.g. Groningen, actively profile the life science sector during national and international fairs, in order to attract investments and business in this sector. ${ }^{57}$ This might partly explain why students tend to stay in the North of the Netherlands: life sciences work placements are available, mainly in smaller and medium sized enterprises. This could also be a consequence of individual preferences since students arrange their own work placements. How this may be, the region profits from the availability of students of the SBP-track. As such, there are indications that SBP functions an economic impulse to the region. Work placements abroad initially have been exceptional but are becoming increasingly common. This may be attributed to the enrolment of more foreign students in the University of Groningen and the fact that the SBP-program recently became available in English (from 2016 onwards). Lastly, while work placement sectors are diverse, work placements in the sectors of healthcare $\&$ pharmacy and agriculture \& environment are most popular. This coincides with expectations, given the science background of SBP-students - mostly in biomedical sciences and biology.

Third, work placement advice reports were screened, focusing on types of advice given, position in stages of business and policy cycle, business and policy tools applied, position of tools in phases of the loop model, and source usage in the report. As expected, there was a diversity in the stages in business and policy cycles applied in the advices. This underlines that various components of the business and policy cycle can be used effectively within advice reports, for different types of advice. In addition, multiple business and policy tools are used, as well as tools offered in several phases

57 “Gemeenterekening 2018”, Gemeente Groningen, accessed September 29, 2020, https:/gemeente.groningen.nl/sites/default/files/Gemeenterekening-2018-Groningen.pdf. 
of the loop model. These results suggest that a tailored, yet broad theoretical framework for SBP-students supported the quality of their advice report. That is, in order to make individual work placement assignments successful for this master's track, there should be room for a variety of tools that can be used interdisciplinary, yet still fitting within the framework of science, business and policy. Besides the diversity of tools found in the advice reports, the alignment in, and the sufficiency of the offered business and policy tools strengthen this finding.

Furthermore, students integrated a large number of scientific references and external contacts in their advice reports. The data suggest that students carried out a thorough literature search for their advice reports. In addition, students' references to external contacts showed the expansion of their professional network with contacts who contributed to their science advice report. Please note that the real expansion of student's professional network might be higher, since only the explicitly mentioned sources have been recorded.

Fourth, work placement grades, and grades of business and policy exams were compared. It should be noted that there were slight changes in didactics due to the continuing development of the SBP-track. Although the learning objectives remained the same throughout the years, assessment methods (such as assessment rubrics) changed slightly. The results can therefore only be interpreted as explorative, and conclusions that are drawn are formulated with caution.

Grades of all SBP-components varied from sufficient to good. As students choose the topic of their work placement themselves, it was expected that work placement grades were higher than grades for compulsory courses. While differences were not significant, work placement grades tend to be higher than grades for theoretical courses. In addition, business theory grades seem to be higher than the policy theory grades. A possible explanation could be the information density and the nature of business literature, resembling more closely what students are used to during their prior science education. For the policy course, students had to read and disentangle policy documents, often ambiguous and novel. Thus, the policy course may be more difficult than the business course for science students. It could also be due to other (intrinsic) difficulties of the discipline or challenges associated with the way courses are organized.

Business and policy theory grades correlated positively, as well as the work placement grades did with both business and policy theory grades. The correlation values are moderately positive and only grade theory business with grade theory policy (.542 combined, .538 business placements, .555 policy placements) exhibit a considerable positive correlation. This is quite 
understandable as these are both course-based. Table 6 shows a small difference (.326 vs. .299) that seems to suggest that grade work placement for business placements is almost similarly correlated to both grade theory business and policy while Table 7 on all policy placements have a bigger gap (.251 vs. 462). While this should be kept in mind, still, correlations between work placements and matching theory grades were stronger than unmatching theory grades (i.e., business work placements with business theory \& policy work placements with policy theory). As students choose the type of work placement that suits their expertise best, it is not unlikely that grades on theory courses that are more in line with their expected future career (i.e., in the area they carry out their work placement) correlate stronger. These results give indications that it is also possible to evaluate students' academic level by grading their work placement reports, as opposed to evaluating students only based on results on theoretical exams. That is, student quality in the area of business or policy is not only reflected by the results on their business or policy courses, but also by their work placement grades. Based on our results, this is especially true for the policy work placements.

Looking at the SBP-track, it can be concluded that the societal interpretation of the Bologna process has been implemented successfully, by closing the theory-practice gap with academic learning and furthering professional experience using a WBL-approach. This case study showed that a heterogenic population of science students (i.e., students of different disciplines) can address a heterogenic population of problems for business and policy organisations with a very diverse character, sector, size and region, by using a variety of tools and sources.

This diversity can form an educational challenge, since there is no onesize fits all approach possible. However, a WBL-approach, in this case translated to the SBP-track, seems to have the potential to include all the described variety. As such, academic WBL-programs could be an answer to the call from the work floor, but also from students to realize a better connection between achieving academic level and gaining hands-onexperience. In this way, one academic degree does not only comprise of science and societal aspects but is also earned by practical projects and actions that are needed to get there.

\section{VI.3. Future questions}

Besides introducing the theoretical framework applied to design the SBP-track, this article aimed to share possible success factors for academic 
WBL-programs. Simultaneously, we provided some insights into the SBPtrack's student population and their study records. We invite colleagues to share their methods and approaches used to develop academic WBLprograms. Being able to compare different case studies on fulltime bachelor's and master's level WBL-programs has the potential to form a more cohesive and extensive theoretical framework on quality assurance of academic WBLprograms.

In order to improve education, Lester et al. ${ }^{58}$ stress that more in-depth qualitative research based on real programs could also be employed to explore the extent to which different pedagogies and curricular structures support effective learning and develop capability and professionalism in different fields and contexts. This area of research would need to have a longitudinal element to look beyond end-of-program outcomes to the effect on careers and, where relevant, further study. It can also be useful to explore the long-term effects of WBL versus traditional programs on (prior) students. For that reason, we started to investigate SBP-alumni experiences with the WBL-program, and their careers after graduating, in relation to experiences from alumni who graduated in a research-oriented profile.

Furthermore, research about conditions that are needed for successfully implementing a WBL-program within academia can be examined. What does implementing a WBL-program mean for the organisation of education and the qualities needed of the teachers or instructors? An evaluative study is currently conducted with staff of the faculty of Science and Engineering at the University of Groningen to assess professors' perceptions related to the SBP-track.

Finally, it is also important to extend the analysis of the societal impact of WBL. Therefore, we are investigating experiences of the providers of the work placements. Does WBL really help in preparing students for their career and are students able to make a difference within business and policy organisations? Whether the desired societal impact is reached, is currently being verified by carrying out interviews with SBP-supervisors from the societal institutions involved with the SBP-student's work placements.

\section{Bibliography}

Agre, Peter, and Alan I. Leshner. "Bridging Science and Society." Science 327 (February): 921. https://doi.org/10.1126/science.1188231.

${ }^{58}$ Lester, Bravenboer, and Webb, "Work-integrated degrees,“ 34-35, http://devmts.org. uk/wid.pdf. 
Anderson, Terry, and Julie Shattuck. "Design-Based Research: A Decade of Progress in Education Research?" Educational Researcher 41, no. 1 (January 2012): 1625. https://doi.org/10.3102/0013189X11428813.

ApprenticeshipQ. “Quality Apprenticeships: A Manual for Educational Organizations Version 1 Eurashe Report Brussels.” Accessed November 20, 2020. https:// apprenticeshipq.eu/.

Barnett, Ronald. "Supercomplexity and the university." Social Epistemology 12, no 1 (June 1998): 43-50. https://doi.org/10.1080/02691729808578859.

Bezanilla, María José, Ana María García Olalla, Jessica Paños Castro, and Manuel Poblete Ruiz. "A model for the evaluation of competence-based learning implementation in higher education institutions: Criteria and indicators." Tuning Journal for Higher Education 6, no. 2 (May 2019): 127-174. http://dx.doi. org/10.18543/tjhe-6(2)-2019pp127-174.

Bloom, Benjamin Samuel. "Taxonomy of educational objectives: the classification of educational goals; Handbook I: Cognitive domain." In Taxonomy of educational objectives: the classification of educational goals; Handbook I: Cognitive domain, edited by M. D. Engelhart, E. J. Furst, W. H. Hill, and D. R. Krathwohl, New York: David McKay, 1956.

Bolonga Process. "The European Higher Education Area in the new decade." accessed September 29, 2020. https://www .eurashe.eu/library/modernising-phe/ Bologna_2009_Leuven-Communique.pdf.

Bolonga working group. A Framework for Qualifications of the European Higher Education Area. Bologna Working Group Report on Qualifications Frameworks. Copenhagen: Danish Ministry of Science, Technology and Innovation, 2005.

Bos, Jo, and Ernst Harting. Projectmatig creëren ( $9^{\text {th }}$ edition). Schiedam: Scriptum Books, 1998.

Bos, Jo, Ernst Harting, and Marlet Hesselink. Project Driven Creation. Utrecht: Phaos, 2014.

Boud, David, and Nicky Solomon. Work-based Learning: A New Higher Education? Buckingham: SHRE/OU Press, 2001.

Boud, David, Nicky Solomon, and Colin Symes. "New Practices for New Times." In Work-based Learning: A New Higher Education?, edited by David Boud, and Nicky Solomon, 3-17. Buckingham: SHRE/OU Press, 2001.

Brew, Angela. "Transforming Academic Practice through Scholarship." International Journal for Academic Development 15, no 2 (June 2010) 105-116, https://doi. org/10.1080/13601441003737618.

Communiqué of the Conference of European Ministers Responsible for Higher Education. "The Bologna Process 2020 - The European Higher Education Area in the new decade." Accessed September 29, 2020, https://www.eurashe.eu/ library/modernising-phe/Bologna_2009_Leuven-Communique.pdf.

Commission of the European Communities. "Commission Recommendation of 6 May 2003 concerning the definition of micro, small and Medium-sized enterprises (Text with EEA relevance) (notified under document number 
C(2003) 1422)." Official Journal L 124 (May 2003): 36-41. http://data.europa. eu/eli/reco/2003/361/oj.

Conway, Steve, and Fred Steward. Managing and Shaping Innovation. Oxford: Oxford University Press, 2009.

Coolsma, Johan. C., and André J. G. M van Montfort. "De uitvoering van overheidsbeleid." In Overheidsbeleid, Een inleiding in de beleidswetenschap, edited by Andries Hoogerwerf, and Michiel Herweijer, 117-135. Alphen aan den Rijn: Kluwer, 2014.

Dixon Jami, Cody Belnap, Chad Albrecht, and Konrad Lee. "The Importance of Soft Skills." Corporate Finance Review 14, no 6 (June 2010): 35-38.

Donà dale Rose, Luigi F., and Anna Serbati. "20th Anniversary of the Bologna Declaration: From overview of processes to ongoing activities and experiences." Tuning Journal for Higher education 6, no. 2 (May 2019): 13-19. http://dx.doi. org/10.18543/tjhe-6(2)-2019pp13-19.

Dunn, William N. Public policy analysis: An integrated approach. New York, NY: Routledge, 2018.

EHEA. "Quality Assurance.” Accessed September 29, 2020. http://www.ehea.info/ pid34433/quality-assurance.html.

Geerdink, Gerda, Els van der Pol, and Erik Jansen. "Onderzoek in het hbo op de lerarenopleiding primair onderwijs." Tijdschrift voor Hoger Onderwijs en Management, no 1 (2008): 56-61. https://www.themahogeronderwijs.org/hetarchief/author/235.

Gemeente Groningen. “Gemeenterekening 2018. ”Accessed September 29, 2020. https://gemeente.groningen.nl/sites/default/files/Gemeenterekening-2018Groningen.pdf.

Gerkema, Menno. "Timing and innovation”, Inaugural lecture, University of Groningen, Groningen, 2008.

Gerkema, Menno, Eva Karasek, and Henny J. Van der Windt. "Loop model.” In Science, Business and Policy Reader, edited by Gert-Jan W. Euverink, Groningen: University of Groningen, 2016.

Griffioen, Didi M.E., and Uulkje de Jong. "Opvattingen van Docenten en Nietdocenten over Onderzoek in Het Hbo." Tijdschrift voor het Hoger Onderwijs 28, no. 2, (January 2010): 83-95. https://www .academia.edu/217088/Opvattingen_ van_docenten_en_niet-docenten_over_onderzoek_in_het_hbo.

Groot, de Adrianus. Methodology: Foundations of Inference and Research in the Behavioral Sciences. Belgium: Mouton \& Co, 1969.

Hoogerwerf, Andries, and Michiel Herweijer. Overheidsbeleid: Een inleiding in de beleidswetenschap. Alphen aan den Rijn: Kluwer, 2014.

Howard, Cosmo. "The policy cycle: A model of post-machiavellian policy making?" Australian Journal of Public Administration 64, no. 3 (September 2005): 3-13. https://doi.org/10.1111/j.1467-8500.2005.00447.x.

Hsieh, Hsiu-Fang and Sarah Shannon. "Three Approaches to Qualitative Content Analysis." Qualitative health research 15, no. 9 (December 2005): 1277-88. https://doi.org/10.1177/1049732305276687. 
Hulst, Jacqueline. W.M., and Frans Leijnse,. "De veranderagenda: de organisatie van het onderzoek in de hogescholen." Tijdschrift voor Hoger Onderwijs en Management, no. 1 (2007): 47-54. https://www.themahogeronderwijs.org/hetarchief/author/3.

Johnson, Gerry, and Kevan Scholes. Exploring Corporate Strategy (6 $6^{\text {th }}$ Edition). Edinburgh Gate: Financial Times Prentice Hall, 2002.

Juszczyk, Stanisław. "The Bologna Process and the European Higher Education Area.” Korean journal of European integration 7 (September 2013): 89-115.

Kamann,Dirk-Jan F. Externe Organisatie:een inleiding vanuiteennetwerkperspectief. Groningen: Charlotte Heymanns Publishers, 2003.

Keeling, Ruth. "The Bologna Process and the Lisbon Research Agenda: the European Commission's expanding role in higher education discourse." European Journal of Education 41, no 2. (June 2006): 203-223 https://doi. org/10.1111/j.1465-3435.2006.00256.x.

Lester, Stan, Darryll Bravenboer, and Neville Webb. "Work-integrated degrees: context, engagement, practice and quality." Quality Assurance Agency for Higher Education (September 2016): 1-49. https://doi.org/10.13140/ RG.2.2.35788.21129.

Lester, Stan, and Carol Costley. "Work-based learning at higher education level: value, practice and critique", Studies in Higher Education 35, No. 5 (August 2010): 561-575. https://doi.org/10.1080/03075070903216635.

Leydesdorff, Loet. A., and Henry Etzkowitz. "Emergence of a Triple Helix of University-Industry-Government Relations." Science and Public Policy 23, no. 5 (1996): 279-86. https://www.leydesdorff.net/th1a/.

Leydesdorff, Loet. A., and Henry Etzkowitz. "The Triple Helix as a model for innovation studies." Science and Public Policy 25, no 3 (1998) 195-203, https:// doi-org.proxy-ub.rug.nl/10.1093/spp/25.3.195.

Marín, Nicolás, Alicia Benarroch, and Jimenez E. Gomez. "What is the relationship between social constructivism and Piagetian constructivism? An analysis of the characteristics of the ideas within both theories." International Journal of Science Education 22, no.3 (July 2010): 225-238, https://doi.org/10.1080/095006900289840

Schön, Donald, A. The Reflective Practitioner: How Professionals Think in Action. New York: Basic Books, 1983.

Schön, Donald, A. Educating the reflective practitioner. San Francisco: Jossey-Bass Publishers, 1987.

Staa, van, AnneLoes, and Kirsten de Vries. "Directed content analysis: een meer deductieve dan inductieve aanpak bij kwalitatieve analyse." KWALON 19, no 3 (May 2016): 46-54. https://www.tijdschriftkwalon.nl/inhoud/tijdschrift_artikel/ KW-19-3-46/Directed-content-analysis-een-meer-deductieve-dan-inductieveaanpak-bij-kwalitatieve-analyse.

Stamm, von Bettina. Managing innovation, design and creativity. Hoboken: John Wiley \& Sons, 2008.

Turner, Rodney, J. The handbook of project based management (2th edition). London: McGraw-Hill, 1999. 
Wagenaar, Robert. REFORM! TUNING the Modernisation Process of Higher Education in Europe: A Blueprint for Student-Centred Learning. Groningen: University of Groningen, 2019.

"Work placement Business and Policy." University of Groningen. Accessed April 09 2021. https://www.rug.nl/ocasys/fwn/vak/show?code=WMSE901-40.

De Weert, Egbert. "The Netherlands." In International Handbook of Higher Education, edited by James J.F. Forest, and Philip, G. Altbach, 899-918. Dordrecht: Springer, 2006.

WEXHE. "What is Work-based Learning (WBL)." Accessed September 29, 2020. https://wexhe.eu/index.php/2017/05/09/what-is-work-based-learning-wbl/.

\section{About the authors}

SASKIA GROOTERS (s.grooters@rug.nl) is lecturer and coordinator of the workbased learning track Science, Business and Policy (SBP) at the Faculty of Science and Engineering of the University of Groningen. The SBP-track was selected in 2018 as a best case practise of WBL in Europe (WEXHE project, European Union). She develops educational programs based on projects in real life, working with students in experience-based learning and based on intensive contact with the professional field. An example of a program co-developed by her is a university broad minor called Future Planet Innovations where students work interdisciplinary on sustainability issues in real live group projects and serious games. Her own education comprises master degrees in Biomedical Sciences, Neurosciences, and Psychology. She combines her theoretical knowledge of these fields with her experience in the corporate world.

EMMA L. ZAAL (e.1.zaal@rug.nl) is a PhD-candidate at the Faculty of Arts, University of Groningen. In her PhD-project, Emma investigates how socially desirable responding can best be predicted, measured and reduced in online questionnaires. She graduated cum laude from the University of Groningen in 2018 in the research master's Linguistics: Language \& Cognition and in the regular master's Computer Communication, where she specialized in persuasive communication and socially desirable responding in the behavioural fields of health and sustainability. Emma has worked as a research-assistant at the Faculty of Science and Engineering, where she investigated the societal impact of the work-based learning track Science, Business and Policy. In addition, Emma is a lecturer in Communication and Information Sciences, and teaches courses like questionnaire- and interview design at the Faculty of Arts of the University of Groningen.

MENNO P. GERKEMA (m.p.gerkema@rug.nl) is emeritus professor of Chronobiology, and Science, Business and Policy at the University of Groningen. Besides research and teaching Chronobiology and Science and Society, he developed the Science master's curriculum for the work-based learning track Science, Business and Policy. He is co-founder of the spin-off company 
Chrono@Work. His main fields of chronobiological research consist of ultradian rhythms in animal behaviour, neurophysiological regulation of circadian output, mechanisms of daily memory, evolution of night- and day active behaviour and long-term consequences of shift-work. He supervised various PhD-projects on Science and Society interactions and currently studies the impact of work-based learning in the context of the Science, Business and Policy track. 


\title{
Science, Business, and Policy: A long-term reflection on multidisciplinary work-based learning in a master's track for societal integration of Science
}

\author{
Saskia Grooters, Emma L. Zaal, and Menno P. Gerkema
}

doi: http://dx.doi.org/10.18543/tjhe-8(2)-2021pp119-164

\section{Copyright}

Copyright for this article is retained by the Publisher. It is an Open Access material that is free for full online access, download, storage, distribution, and or reuse in any medium only for noncommercial purposes and in compliance with any applicable copyright legislation, without prior permission from the Publisher or the author(s). In any case, proper acknowledgement of the original publication source must be made and any changes to the original work must be indicated clearly and in a manner that does not suggest the author's and or Publisher's endorsement whatsoever. Any other use of its content in any medium or format, now known or developed in the future, requires prior written permission of the copyright holder. 